\title{
Nível de conhecimento dos tratadores rurais relacionado a práticas de manejo e sanidade de bezerros no município de Batalha/AL
}

Rayane Caroline Medeiros do Nascimento, Lucas Adonys Teixeira da Silva, Viviane Melo Coelho Barros, Walter Franklin Bernardino Leão Filho, George Tenório Pereira de Oliveira, Gabriel Regis Guerrieri Esperidião, Anderson Silva de Oliveira, Wagner José Nascimento Porto1, Andressa Rodrigues Sabino, Gildeni Maria Nascimento de Aguiar

Curso de Medicina Veterinária, Unidade Educacional de Viçosa, Universidade Federal de Alagoas (UFAL), Arapiraca, AL, Brasil

*Autor correspondente

e-mail: gildeni.aguiar@vicosa.ufal.br

\section{Resumo}

Os rebanhos nacionais destinados à produção de leite bovino são, em sua maioria, geridos por agricultores familiares, que possuem um baixo grau de escolaridade e conhecimento técnico. Diante disso, o presente trabalho objetiva determinar o grau de conhecimento dos produtores rurais em relação às enfermidades e às medidas de manejo destinadas aos bezerros de leite no município de Batalha, Alagoas. Entre agosto e dezembro de 2016 foram visitadas 21 propriedades para a realização de entrevistas com os responsáveis pelos animais. Foram entrevistados 25 trabalhadores, dos quais 60\% (15/25) tinham ensino fundamental incompleto, $12 \%$ (3/25) até o médio completo, 8\% (2/25) o médio incompleto, apenas 4\% (1/25) superior completo e16\% (4/25) deles nunca estudaram. Algumas medidas de manejo são realizadas de forma correta e as principais razões para sua implementação são conhecidas, como por exemplo: respeito ao período seco da vaca, sendo que 40\% (10/25) relacionaram-no ao aumento da produtividade na lactação seguinte; parto próximo à residência, devido ao rápido auxílio no momento do parto (60\% - 15/25); oferecimento do colostro ao bezerro (76\% - 19/25), relacionado ao desenvolvimento de animais mais fortes e nutridos. A função do colostro na transmissão de imunidade passiva e prevenção das doenças do neonato não é reconhecida pelos produtores, visto que 64\% (16/25) deles não correlacionam a ingestão de colostro e a manifestação do quadro de diarreia; $24 \%$ (6/25) dos produtores acreditam que o colostro possa causar diarreia nos bezerros. 0 consumo de grande quantidade de leite foi acusado por 56\% (14/25) como causa de diarreia; apenas 4\% (1/25) o relacionaram à enfermidade com a demora ao ofertar o colostro. Sabe-se que o momento de ingestão de colostro após o nascimento, a quantidade ingerida e a qualidade do mesmo são fundamentais para a aquisição de imunoglobulinas do neonato. 0 reconhecimento da importância da colostragem entre aqueles que lidam diretamente com os bezerros é essencial para a prevenção de doenças do período neonatal. A maioria dos entrevistados, 96\% (24/25), não conhecia as estruturas que compunham 
o umbigo, embora tivessem noção das consequências negativas quando este não era curado - miíase (32\% -8/25), hérnias (12\% -3/25), onfalites (28\% -7/25) ou morte (8\%-2/25) -, e 20\% (5/25) não souberam responder. A maioria dos entrevistados não tinha ideia a respeito das possíveis causas de broncopneumonia (60\%-15/25) ou associavam-na a mudanças climáticas, 28\% (7/25), ou à ingestão de areia, pó ou água suja (12\%-3/25). Por mais que estejam plenamente difundidas as medidas preventivas relacionadas à sanidade dos bezerros, o repasse dessas recomendações deve ser compatível à realidades dos produtores, visando sanar as dificuldades dos tratadores em fazer uma relação entre fatores desencadeantes e manifestações clínicas da doença, objetivando, assim, reduzir a resistência à adoção de medidas profiláticas. 